\title{
Teorie pravdy v tzv. středním komentáři Waltera Burleyho k Aristotelovu Perihermeneias*
}

Jakub Varga

Filosof a teolog první poloviny čtrnáctého století Walter Burley nesepsal žádný text zabývající se výhradně problematikou pravdy. Přesto je zřejmé, že otázky související s pravdou považoval za nanejvýš důležité, čemuž nasvědčuje i jeho tvrzení, že jedním z cílů logického bádání je odlišení pravdy od nepravdy. ${ }^{1} \mathrm{Z}$ děl, pod nimiž je Doctor planus et perspicuus autorsky podepsán, jsou pro dané téma stěžejní zejména dvě. V prvním př́padě jde o jeho raný komentář k Aristotelovu O vyjadřová$n i{ }^{2}$ jenž vznikl někdy v rozmezí let $1302-1310 .{ }^{3}$ Druhým z nich je pozdní soubor komentárư $\mathrm{k}$ tzv. Ars vetus z roku 1337, zejména pak v něm obsažené komentáře ke Kategoriím a $O$ vyjadřování. ${ }^{4}$

Mezi Burleyho ranou a pozdní teorií pravdy existují významné odlišnosti, především pak $\mathrm{v}$ tom, co lze označit jako pravdu logickou. Zatímco v prvním představení svého pojetí pravdy Burley ze všech tzv. vlastností termínů ${ }^{5}$ staví do popředí signifikaci (significatio) ${ }^{6}$ a zcela opo-

* Studie vznikla v rámci projektu SGS15/FF/2016-2017 - Realita a skutečnost ve středověku.

1 W. Burley, Expositio super Artem Veterem Porphyrii et Aristotelis, Benátky: 1497 (přetištěno ve Frankfurtu: 1967), fol c3 vb: „Logicus tamen ut logicus non habet occupari circa verba nisi quantum ad loquendum est discernendum verum a falso."

2 W. Burley, Commentarius in librum Perihermeneias Aristotelis (Commentarius medius), ed. S. F. Brown, Franciscan Studies 33 (1972): 45-134.

3 Pro kompletní bibliografii Waltera Burleyho a datace viz M. VitTorinI, „Life and Works," in A Companion to Walter Burley, ed. A. D. Conti, Boston: Brill, 2013, s. 46-47.

4 Burley, Expositio super Artem Veterem Porphyrii et Aristotelis.

5 Podle Waltera Burelyho, stejně jako podle jiných logiků třináctého a čtrnáctého století, může mít termín několik vlastností, z nichž některé mohou být nekontextuální, tj. takové, které může mít termín i v př́ípadě, stojí-li samostatně, a jiné čistě kontextuální, které se vztahují na termín pouze v př́padě, stojí-li tento termín na pozici extrému $\mathrm{v}$ propozici. Za nekontextuální považuje Burley pouze signifikaci. Z vlastností kontextuálních pak ve svém pojednání De puritate artis logicae jmenuje supozici, kopulaci a apelaci. Viz W. Burley, De puritate artis logicae: Tractatus longior. With a Revised Edition of the Tractatus Brevior, ed. P. Boehner, New York: The Franciscan Institute, 1955, s. 1. 
míjí supozici (suppositio), ${ }^{7} \mathrm{v}$ textu z pozdějšího období hraje supozice přinejmenším stejně klíčovou roli jako pojem signifikace. Právě kvůli tomuto hlavnímu rozdílu ${ }^{8}$ se tato studie zaměří především na Burleyho pojetí pravdy $\mathrm{v}$ jeho raném podání a pozdní teorii ponechá pro možný budoucí badatelský zájem. ${ }^{9}$

K teorii vlastností termínů obecně viz např. S. READ, „Medieval Theories: Properties of Terms," in The Stanford Encyclopedia of Philosophy, ed E. N. Zalta, http://plato.stanford. edu/entries/medieval-terms/ [zveřejněno 12. 2. 20015, cit. 16. 11. 2016]. Klogice v pozdním středověku viz P. V. SPADE, Thoughts, Words and Things: An Introduction to Late Mediaeval Logic and Semantic Theory, http://pvspade.com/Logic/docs/Thoughts, $\% 20$ Words\%20and\%20Things1_2.pdf [zveřejněno 2007, cit. 16. 11. 2016].

6 Signifikace byla ve středověku obvykle chápána jako nekontextuální relační vlastnost termínu, přičemž nešlo pouze o vlastnost sémantickou, ale také psychologicko-epistemologickou. Latinské sloveso "significare“ tak v podstatě znamená totéž jako slovní spojení "constituere intellectum“. Řekneme-li tedy, že např. termín „člověk" primárně signifikuje univerzální přirozenost „člověk“, znamená to, že to, na co primárně pomyslí osoba znající toto substantivum $\mathrm{v}$ českém jazyce, je právě tato obecnina (resp. pomyslí na pojem „člověk“ jsoucí v duši). Pro chápání signifikace nejen u Burleyho viz např. J. VARGA, "Signifikace v díle Waltera Burleyho: Lze se obejít bez její definice?," Aither 5, č. 9 (2013): 70-98, ale také Spade, Thoughts, Words and Things, s. 51-187.

7 U mnoha badatelů z posledních několika desetiletí se lze setkat s tvrzením, že supozice jakožto kontextuální vlastnost termínů může být s jistými rozdíly chápána jako ekvivalent toho, co je v dnešní filosofii označováno jako „reference“. Walter Burley sám definoval supozici takto: „Suppositio generaliter dicta est acceptio termini pro aliquo, scilicet pro re, vel pro voce, vel pro conceptu." Viz Burley, De puritate artis logicae, s. 2. K supoziční teorii Waltera Burleyho viz J. VARGA, „,Walter Burley o supozici termínů," Reflexe 48 (2015): 31-55. Obecně např. SPade, Thoughts, Words and Things, s. $243-276$.

8 Rozdílů je ovšem více. Např. zatímco v raném komentáři je v definici pravdy protějškem věci intelekt, v pozdním komentáři stojí na místě intelektu kognitivní mohutnosti obecně. $\mathrm{V}$ případě pravdy $\mathrm{v}$ logickém smyslu pak kvůli aplikaci supoziční teorie dochází také ke změně funkce a statusu tzv. reálné propozice, která již neplní funkci prostředku verifikace propozic (viz dále druhou kapitolu této studie). Kromě toho se zdá, že má Burley co říci i k jiným úsekům z Aristotelových logických textů, v nichž je problematika pravdy zmíněna. Př́kladem může být dvanáctá kapitola Kategorií zatímco v př́padě svých dvou raných verzí výkladu tohoto úseku Aristotelova spisu Burley v podstatě mlčí, ve svém posledním komentári se problémem, který nastínil Aristotelés, důsledně zabývá.

9 Žádná studie, která je mi známá, se Burleyho chápáním pojmu pravdy v jeho raném ani pozdním pojetí $\mathrm{v}$ ucelené podobě nezabývá. S první systematičtější interpretací této problematiky přišel Laurent Cesalli ve své studii věnované Burleyho propozičnímu realismu $\mathrm{z}$ roku 2001. Vzhledem $\mathrm{k}$ tématu své studie se však jen krátce zaměřuje na pravdu v logickém slova smyslu a její ostatní možná chápání zcela opomíjí. Viz L. Cesalli, „Le réalisme propositionnel de Walter Burley,“ Archives d'histoire doctrinale 
Hlavním východiskem $\mathrm{k}$ řešení otázek spojených s pravdou $\mathrm{v}$ tzv. středním komentáŕi $\mathrm{k}$ Perihermeneias je pro Burleyho následující úsek z první kapitoly Aristotelova textu:

Jako pak $\mathrm{v}$ duši jsou někdy myšlenky, aniž jsou pravdivé nebo nepravdivé, a někdy již takové, kterým nutně náleží jedno nebo druhé, tak je tomu i v mluvě, nebot' nepravda a pravda se týká spojení a rozloučení. Jména a slovesa sama o sobě se podobají myšlence bez spojení a rozloučení; př́íkladem je, řekne-li se „člověk“ nebo „bílé" , kdykoli se nepřidá ještě něco dalšího; tu totiž není zajisté ještě ani nepravda, ani pravda. Př́́kladem toho je, že „kozlojelen“ sice něco značí, ale ještě v tom není nic pravdivého nebo nepravdivého, nepřidá-li se k tomu ,jest“ nebo „neni“", a to bud' vůbec, nebo s udáním času. ${ }^{10}$

Ve svém výkladu si Burley všímá, že Aristotelés připisuje pravdivost dvěma entitám. Za pravdivý je totiž možné označit nejen mluvený výraz (vox), ale také jeho protějšek na straně intelektu, nebot mluvené výroky slouží $\mathrm{k}$ vyjádření myšlenek. To ale nelze říci ve všech př́ipadech. Za pravdivé totiž můžeme označit pouze takové mluvené výrazy a myšlen-

et littéraire du moyen âge 68, č. 1 (2001): 155-222. Podobně je tomu také v rozsáhlé monografii téhož autora zaměřené na propoziční sémantiku a ontologii čtyř stř̌edověkých myslitelů - Jana Dunse Scota, Waltera Burleyho, Richarda Brinkleyho a Jana Viklefa. Ačkoli je zde struktuře pojmu pravdy a jejímu ne-logickému chápání věnováno značně více prostoru (cca 2 odstavce), v ústředí stojí vzhledem $\mathrm{k}$ tematické relevanci opět logická pravda, jejíž zkrácená interpretace však slouží zejména k demonstrování jedné z funkcí, kterou v rámci Burleyho logických teorií plní tzv. reálné propozice. Viz L. Cesalli, Le réalisme propositionnel: sémantique et ontologie des propositions chez Jean Duns Scot, Gauthier Burley, Richard Brinkley et Jean Wyclif, Paris: Vrin, 2007, s. 190-192. S obdobným př́stupem se lze setkat i v L. Cesalli, „Meaning and Truth, “ in A Companion to Walter Burley, ed. A. D. Conti, Boston: Brill, 2013, s. 120-122. Pro další literaturu, nesouvisející prímo s Burleyho chápáním pravdy, ale přesto tematicky př́buznou, viz také pozn. č. 26 níže.

10 Aristotelés, O vyjadřování 16a 9-19, přel. A. Kř̌žž, Praha: Nakladatelství ČSAV, 1959, s. 25. Latinsky: Aristotelés/Boethius, Liber Periermenias Aristotelis, ed. L. Minio-Paluello - G. Verbeke, Aristoteles Latinus Database II, 1-2: 1965: „Est autem, quemadmodum in anima aliquotiens quidem intellectus sine vero vel falso, aliquotiens autem cum iam necesse est horum alterum inesse, sic etiam in voce; circa compositionem enim et divisionem est falsitas veritasque. Nomina igitur ipsa et verba consimilia sunt sine compositione vel divisione intellectui, ut ,homo' vel ,album', quando non additur aliquid; neque enim adhuc verum aut falsum est. Huius autem signum: ,hircocervus' enim significat aliquid sed nondum verum vel falsum, si non vel ,esse' vel ,non esse' addatur vel simpliciter vel secundum tempus." Boethiưv latinský překlad Aristotelových spisů je uváděn s ohledem na Burleymu dostupné písemné prameny a autentičnost. 
ky, které, jak upozorňuje Filosof, se týkají spojení (compositio) a rozloučení (divisio). Nekomplexní mluvený výraz (incomplexum) „člověk“, stejně jako jeho signifikát, jímž je mentální termín či pojem „„̌lověk“, sice něco signifikuje, nicméně ne tak, že bychom mohli hovořit o pravdivém a nepravdivém slovu či pojmu. Pravda tedy souvisí pouze s komplexními mluvenými výrazy a myšlenkami (complexa), v nichž je něco prostřednictvím spony predikováno o nějakém subjektu, jako je tomu např. ve větě: „Homo est albus.“ Za nositele pravdivostní hodnoty je tedy možné označit pouze ty entity, které středověcí myslitelé nejčastěji označovali výrazy "propositio“ a "enunciatio", tedy oznamovací věty na úrovni psaného, mluveného a mentálního jazyka. Tvưrcem těchto propozic je vždy intelekt, který vzájemně spojuje jisté entity ( $\mathrm{v}$ př́ípadě kladné propozice), nebo je od sebe odlučuje (v prŕípadě propozice záporné). ${ }^{11}$

Nicméně poté, co Burley takto stručně okomentuje Aristotelův text, dochází $\mathrm{k}$ jedné pochybnosti týkající se Aristotelovy teze o pravdě. Zdá se totiž, že nedokáže vyčerpat všechny entity, na které je a může být aplikován predikát „pravdivý“:

Je nepochybné, že se pravda a nepravda nacházejí tam, kde není ani spojení ani rozloučení. Říká se totiž „pravdivý denár ${ }^{\text {“12 }}$ nebo „nepravdivý“ tam, kde není spojení ani rozloučení. Rovněž jsoucno a pravda jsou konvertibilní a jsoucno se nachází tam, kde není spojení ani rozloučení. Podobně je také smysl vzhledem k vlastnímu předmětu vždy pravdivý, jak tvrdí Filosof v druhé knize $O$ duši, a přesto smysl ani nespojuje, ani nerozlučuje. ${ }^{13}$

11 Burley, Commentarius in librum Perihermeneias 1.2, s. 57: „Hic probatur quod aliqua vox est significativa veri vel falsi, et aliqua non. Et hoc probatur sic: Sicut est in intellectu, sic est in voce, quia signum debet conformari significato, et voces significativae formantur ad exprimendum conceptiones intellectus, et ideo sicut est in intellectu sic est in voce. Sed intellectus quandoque est sine vero et sine falso et quandoque cum vero et cum falso, igitur sic est in voce quod quaedam est significativa veri vel falsi, et quaedam non. Est enim quandoque cum vero quandoque cum falso, quando intellectus componit res ad invicem vel dividit eas ab invicem, et ideo dicit Philosophus quod ,circa compositionem et divisoinem consistit veritas et falsitas.' Sed cum intellectus intelligit simplicem quidditatem rei absolute nec est veritas nec falsitas. Ex hoc concluditur quod nomina et verba per se sumpta nec significant vera nec falsa sed sunt similia intellectui sine vero et sine falso, et hoc patet ex hoc qoud dictum est circa compositionem et divisionem."

12 V jazyce českém bychom se mohli setkat spíše se spojením „,skutečný denár“ či „pravý denár". V latině se však užívaly fráze „denarius verus" a "denarius falsus“, což se $\mathrm{v}$ českém překladu pokouším zohlednit.

13 Burley, Commentarius in librum Perihermeneias 1.21, s. 58: „Indubium quod veritas et falsitas reperiuntur ubi nec est compositio nec divisio. Dicitur enim denarius verus vel falsus ubi nec est compositio nec divisio. Similiter, ens et verum convertuntur et ens 
Zdá se tedy, že Aristotelovo tvrzení z počátku Perihermeneias nedokáže postihnout pravdu v její úplnosti, ale vystihuje pouze její jeden aspekt či jednu aplikaci pojmu pravdy, konkrétně na oblast logické pravdy, a ignoruje oblasti další - např. epistemologickou a metafyzickou. ${ }^{14}$ Logická oblast je sice $\mathrm{v}$ daném kontextu (tj. v komentáři $\mathrm{k} O$ vyjadřování) nejdůležitější, rozsah entit, které jsou či mohou být nositeli pravdivostní hodnoty, je přesto mnohem širší. Dokonce je možné říci, že je v rámci možností nejširší, nebot pravda se v jistém smyslu vyskytuje všude tam, kde je jsoucno. Jelikož však pravda není se jsoucnem identická, vyžaduje svou vlastní definici.

Vymezení pravdy, které ve svém textu Doctor planus et perspicuus uvádí, lze chápat jako variaci na „klasickou“ adekvační definici, kterou můžeme znát např. z Akvinského spisu De veritate, konkrétně definici, dle které je pravda shoda intelektu a věci. ${ }^{15}$ Přesto jsou zde i výrazné odlišnosti. Burleyho definice má specifickou strukturu, nebot' existují dva základní zpưsoby, jak je třeba pravdu chápat, z nichž každý je dělen do dvou dalších.

Jelikož je zřejmé, že se Burley v daném kontextu soustředí především na pravdu v logickém slova smyslu, tj. na pravdu propozic, které jsou logickým nositelem pravdivostních hodnot, bude i v tomto článku stát v ústř̌edí právě pravda propoziční, jíž je věnován druhý oddíl. První část této studie se pak zaměří na pravdu chápanou ontologicky (tj. jako prav-

reperitur ubi nec est compositio nec divisio. Similiter, sensus respectu proprii obiecti semper est verus, ut dicit Philosophus, II De anima, et tamen sensus nec componit nec dividit."

Všechny v této studii uváděné české překlady textů Waltera Burleyho jsou mé vlastní.

14 Burley ovšem zcela neignoruje jiná Aristotelova tvrzení o pravdě. Jak bude ukázáno později, své pojetí pravdy se snaží zasadit do širšího aristotelského rámce a odkazuje např. na jedno Aristotelovo tvrzení z Metafyziky týkající se pravdy, které interpretuje ontologicko-teologicky. Aristotela tedy neobviňuje z pochybení, jak by se mohlo na první pohled zdát. Naopak si uvědomuje, že Aristotelés takto hovoří o pravdě hlavně z toho důvodu, že ji řeší v kontextu čistě logických zkoumání.

15 Viz např. T. Aкvinskŕ, Quaestiones disputatae de veritate, Editio Leonina, q. 1, a. 1, s. 6, 184-187, kde Akvinský (zřejmě mylně) přisoudil tuto definici Izáku Izraelimu: „Alio modo definitur secundum id in quo formaliter ratio veri perficitur; et sic dicit Isaac quod veritas est adaequatio rei et intellectus." Pro chápání pravdy u Tomáše Akvinského a jeho adekvační definici viz např. J. F. WIPPEL, „Truth in Thomas Aquinas," The Review of Metaphysics 43, č. 2 (1989): 295-326, a J. F. WIPPEL, „Truth in Thomas Aquinas, Part II," Review of Metaphysics 43, č. 3 (1990): 543-567. Pro tuto definici obecně viz např. J. A. Aertsen, Medieval Reflections on Truth: Adaequatio rei et intellectus, Amsterdam: 1984. 
du bytí) a epistemologicky. Ústřední otázka tohoto textu tak může být následující: co je to podle Burleyho pravda? Nicméně vzhledem $\mathrm{k}$ tomu, že se pravda $\mathrm{v}$ jednom $\mathrm{z}$ možných smyslů tohoto slova týká propozic, je třeba si položit ještě další otázku: Jaký vztah má propoziční pravda $\mathrm{k}$ tomu, co Walter Burley označil jako propositio in re (tj. reálné propozice)?

\section{Pravda bytí a pravda poznání}

V prvním smyslu (1) definuje Burley pravdu jako shodu věci s intelektem (adaequatio rei ad intellectum). Tuto definici se pak snaží vysvětlit těmito slovy:

$\mathrm{V}$ tom smyslu, že je pravda shodou věci s intelektem, je pravda vlastností věci, skrze kterou se přirozeně odkrývá intelektu, a odkrývá se intelektu tak, že se jeví takovou, jakou je. ${ }^{16}$

V tomto smyslu je tedy pravda vlastností, kterou přirozeně disponuje každá věc. Ačkoli jde o vlastnost náležející věci, jedná se stále o vlastnost relační, a proto je $\mathrm{k}$ jejímu uskutečnění nutný ještě druhý člen této relace - intelekt, který je proto podmínkou nutnou $\mathrm{k}$ tomu, aby pravda $\mathrm{v}$ tomto smyslu mohla nastat. Na otázku per impossibile, zda by existovala pravda $\mathrm{v}$ tomto smyslu i v př́padě neexistence žádného intelektu, a tedy i božského, by tedy Burley zřejmě odpověděl, že nikoli, nebot' $\mathrm{k}$ tomu, aby byla tato relace uskutečněna, musí existovat obě její relata.

Jelikož však intelekt může být dvojí, konkrétně božský či nestvořený na straně jedné a lidský či stvořený na straně druhé, a jelikož existuje rozdíl v tom, je-li věc poznána intelektem božským či intelektem lidským, je nutné zavést také distinkci v takto pojaté pravdě na základě toho, vzhledem k jakému intelektu je daná relace uskutečněna. ${ }^{17}$

16 Burley, Commentarius in librum Perihermeneias 1.22, s. 59: „Secundum quod veritas est adaequatio rei ad intellectum sic veritas est proprietas rei per quam nata est manifestare se intellectui, ita quod sic manifestat se intellectui quod apparet talis qualis est."

17 Burley, Commentarius in librum Perihermeneias 1.22, s. 59: „Et hoc potest esse dupliciter, quoniam res cognoscitur $\mathrm{ab}$ intellectu humano et ab intellectu divino. Et secundum hoc veritas quae est adaequatio rei ad intellectum est duplex: Quia quaedam est veritas per quam res manifestat se intellectui divino et quaedam est veritas per quam res manifestat se intellectui humano." 
$\mathrm{V}$ př́padě pravdy jakožto shody věci s božským intelektem (1a) je možné ŕíci, že se jedná o vlastnost, která náleží každému jsoucnu bez výjimky. Žádná věc totiž nemůže zůstat božskému intelektu skryta, nebở každá věc se jeví božskému intelektu taková, jaká je. $V$ daném případě je tedy možné hovořit o jisté univerzální otevřenosti jsoucna vzhledem k božskému intelektu. Navíc, jak si Burley všímá, právě v tomto smyslu je pravda také tím, co je konvertibilní s pojmem jsoucna (tj. oba pojmy jsou extenzionálně identické), nebot každé jsoucno je doprovázeno pravdou tohoto druhu. Kromě toho Burley také připomíná Aristotelovu tezi z Metafyziky, že „všechno je také k pravdě v takovém poměru, v jakém je k jsoucnosti, ${ }^{~} 18$ která dle jeho slov dané definici odpovídá. ${ }^{19}$

Pokud ovšem uchopíme pravdu jako shodu věci s naším či stvořeným intelektem (1b), je pravda vlastností věci, prostřednictvím které věc přirozeně utváří pravdivé mínění (ferre veram aestimationem) o sobě. Burley zde připomíná Anselmovu definici pravdy jakožto správnosti (rectitudo), ${ }^{20}$ ačkoli jej prŕmo nejmenuje. Za pravdivou lze tedy označit entitu tehdy, když činí (či má) to, co by činit (či mít) měla, a to v tom smyslu, že se lidskému intelektu nejeví jinak, než jak (in re) je. V třetí formulaci pak Burley užívá termín "signifikace“" v širším slova smyslu, ${ }^{21} \mathrm{v}$ němž lze jako znak chápat jakoukoli entitu, nejen entitu jazykovou. Nějakou entitu tak můžeme označit za pravdivou tehdy, pokud intelektu signi-

18 Aristotelés, Metafyzika 993b 31-32, přel. A. Kř́žz̆, Praha: Petr Rezek, 2008, s. 66.

19 Burley, Commentarius in librum Perihermeneias 1.22, s. 59: „Veritas primo modo dicta est quaedam proprietas communis consequens quodlibet ens, quia quodlibet ens est natum manifestare se intellectui divino sicuti est, unde nulla res potest apparere intellectui divino altera quam est. Ut verum denominatum a veritate sic dicta est verum quod convertitur cum ente, et de vero sic dicto dicit Philosophus II Metaphysicae, quod sicut aliquid se habet ad entitatem, sic ad veritatem, et falsum in entitate est falsum in veritate."

20 Srov. Anselm, Dialogus de veritate 11, PL 158,479: „Possumus igitur, nisi fallor, diffinire quia veritas est rectitudo sola mente perceptibilis."

21 Tj. jako signifikaci týkající se všech entit, které mohou intelektu něco signifikovat. Tak lze kupř́íladu říci, že kouř stoupající $\mathrm{k}$ nebi signifikuje jedinci, který tento kouř $\mathrm{z}$ dálky vidí, to, že někde hoří. Srov. také definici znaku sv. Augustina a jim uváděné příklady: „Signum est enim res praeter speciem, quam ingerit sensibus, aliud aliquid ex se faciens in cogitationem venire. ... sicut vestigio viso transisse animal cui vestigium est, cogitamus; et fumo viso, ignem subesse cognoscimus; et voce animantis audita, affectionem animi eis advertimus, et tuba sonante milites vel progredi se vel regredi, et si quid aliud pugna postulat, oportere moverunt." Augustinus Hipponensis, De doctrina Christiana 1, 2, 1, ed. J. Martin, in CCSL 32, Turnhout: Brepols, 1962. 
fikuje pravdu, za nepravdivou pak tehdy, pokud intelektu signifikuje nepravdu. ${ }^{22}$ Burley to demonstruje na prríkladu s denárem:

Proto má-li něco formu denáru, signifikuje, že je denárem stř́brným; a je-li stříbrným denárem, signifikuje pravdu a je pravdivým denárem; a pokud není stř́brným, signifikuje nepravdu a je denárem nepravdivým. ${ }^{23}$

(1) Adaequatio rei ad intellectum

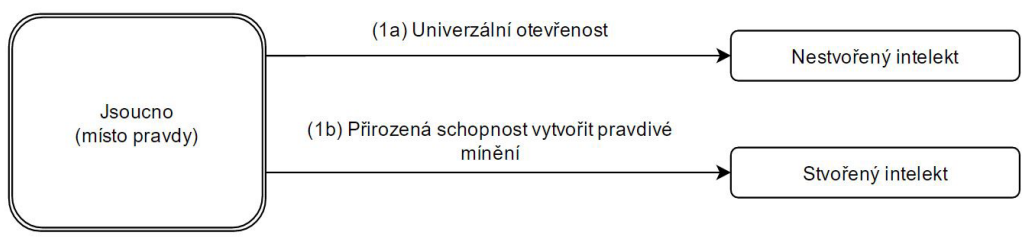

Obr. 1: Pravda jako shoda věci s rozumem

Oba tyto druhy pravdy pojaté jako shoda věci s intelektem lze chápat tak, že se pravda nachází ve věcech. $Z$ toho důvodu lze hovořit o pravdě ontologické. Tato vlastnost, která náleží věcem, se v nich ovšem nachází

22 Burley, Commentarius in librum Perihermeneias 1.23, s. 59: „Acipiendo veritatem secundo modo, ut scilicet est adaequatio rei ad intellectum nostrum, sic veritas est proprietas rei per quam res nata est de se ferre veram aestimationem. Et sic dicitur denarius verus, qui apparet esse verus denarius et in rei veritate est verus denarius, et iste dicitur falsus denarius qui apparet esse verus denarius et non est. Isto modo dicitur illud esse verum quod fit eo modo quo fieri debet. Unde veritas isto modo est quaedam rectitudo, ita quod illud dicitur verum quod facit vel habet illud quod facere vel habere deberet, ita quod non est natum apparere alterum quam est. Et posset dici quod isto modo dicitur aliquid verum quod intellectui significat verum, vel falsum quod intellectui significat falsum. "Srov. také T. Aкvinskŕ, Quaestiones disputatae de veritate, Editio Leonina, q. 1, a. 2, s. 9, 107-112: „... secundum autem adaequationem ad intellectum humanum dicitur res vera, in quantum est nata de se facere veram aestimationem; sicut e contrario falsa dicuntur quae sunt nata videri quae non sunt, aut qualia non sunt..."

23 Burley, Commentarius in librum Perihermeneias 1.23, s. 59: „Unde quodlibet habens formam denarii significat se esse denarium argenteum; et si sit denarius argenteus, significat verum et est verus denarius; et si non sit argenteus, significat falsum et est denarius falsus." 
pouze $\mathrm{v}$ jejich vztahu k intelektu, at’ už jde o intelekt božský či lidský, nebot' jde o schopnost věci vytvořit $\mathrm{v}$ intelektu reprezentaci sebe sama. $\mathrm{Z}$ toho důvodu je vhodné hovořit o této pravdě jako o ontologicko-epistemologické vlastnosti věci.

Ve druhém smyslu (2) je pravda shoda intelektu s věcí (adaequatio intellectus ad rem). $\mathrm{V}$ tomto př́padě Doctor planus et perspicuus nepřichází s žádným rozšířeným vysvětlením tohoto modu pravdy a přechází rovnou k definici dvou druhů, do nichž je rozdělena.

V prvním př́ípadě (2a) lze hovořit o pravdě čistě epistemologické. Jakmile totiž věc vytvoří kompletní poznání o sobě v intelektu tak, že se $\mathrm{v}$ něm nachází její úplná reprezentace, můžeme říci, že v něm existuje pravda. Burley zde poznamenává, že takto hovoříme o pravdě v případě jednoduchého uchopení (comprehensio/apprehensio simplex) věci, tedy první operace intelektu. A dodává, že v tomto př́padě můžeme dokonce tvrdit, že je pravdivý i smyslový vjem (sensus). Pokud totiž vlastní předmět smyslu (např. zraku) vytvoří ve smyslu úplnou reprezentaci sebe sama, můžeme říci, že je smysl pravdivý. Totéž pak platí o samotném intelektu. Nebở tehdy je možné tvrdit, že kognitivní mohutnost, at už smyslová či racionální, získala úplné poznání svého předmětu, které má nyní k dispozici ve formě reprezentující daný předmět. Proto v těchto př́padech můžeme říci, že je smysl či intelekt ve shodě s věcí. ${ }^{24}$

\section{Propoziční pravda}

Nicméně, jak si Burley všímá, pod žádný z popsaných modů pravdy nespadá Aristotelovo tvrzení z textu $O$ vyjadřování, dle něhož se pravda týká spojení a rozloučení. Proto je nutné zavést druhý typ pravdy $(2 b)$ spadající pod definici, dle které je pravda shoda intelektu s věcí, který

24 Burley, Commentarius in librum Perihermeneias 1.24, s. 60: „Alio modo est veritas adaequatio intellectus ad rem, et hoc potest esse dupliciter: Aut quia intellectus habet completam notitiam de re... Veritas primo modo dicta potest esse circa comprehensionem simplicium; quando enim res de se facit completam notitiam, tunc est veritas primo modo dicta in intellectu. Et hoc modo dicitur quod sensus est verus circa proprium obiectum, quia sensus habet perfectam cognitionem de suo obiecto. Et cum res non facit de se completam notitiam in intellectu, tunc est falsitas in intellectu, quia tunc intellectus non est adaequatus rei." 
by odpovídal Aristotelově tezi. ${ }^{25} \mathrm{~V}$ tomto př́padě jde o pravdu, která souvisí s druhou operací intelektu, jež je označována jako "tvrzení" (assertio). Výsledkem této činnosti je propozice, kladná či záporná, která je nositelem pravdivostní hodnoty. ${ }^{26}$ Před uvedením Burleyho definice pravdy je však vhodné poukázat přinejmenším na dvě distinkce, které jsou v jeho díle $\mathrm{v}$ daném kontextu užívány:

Za prvé je nutné rozlišovat mezi reálným jsoucnem (ens reale) a jsoucnem umenšeným (ens diminutum). Pravda, jejímž nositelem je propozice, není podle Burleyho reálným jsoucnem, nebot pokud by tomu tak bylo, nebyla by produktem intelektu. Pokud by však nebyla vytvořená intelektem a byla by stále $\mathrm{v}$ duši, pak by se stejně jako $\mathrm{v}$ př́padě pojmu jednalo spíše o podobnost věci (similitudo rei), která je sice něčím, co existuje v duši, ale není podle Burleyho produkována intelektem, ale spíše předmětem kognitivní mohutnosti. $V$ takovém případě by nebylo nutné hovořit o nějakém zvláštním druhu pravdy, ale stačilo by upravit definici (2a). Nositel pravdivostní hodnoty, jímž je propozice, je tedy umenšeným jsoucnem vytvořeným duší. ${ }^{27}$

25 Burley, Commentarius in librum Perihermeneias 1.24, s. 60: „Sed, de vero nullo istorum modorum dicto intelligitur illud quod dicitur in littera: ,Circa compositionem et divisionem etc."

26 Pro propoziční teorii a sémantiku W. Burleyho viz nap̌̌. J. VARGA, „Propoziční sémantika Waltera Burleyho," Filozofia 71 (2016): 474-486, či Cesalli, „Meaning and Truth,“ s. 122-129, či J. BIARD, „Le statut des énoncés dans les commentaires du Peri Hermeneias de Gauthier Burley," in The Commentaries on Peri Hermeneias in the Middle Ages, ed. H. A. G. Braakhuis - C. H. Kneepkens, Haaren, 2004, s. 103-118. Pro specifičtější témata spojená s touto problematikou viz např. A. ConTI, „Significato e verità in Walter Burley," Documenti e studi sulla tradizione filosofica medievale 11 (2000): 317-350, E. KARGER, „Mental Sentences According to Burley and Early Ockham,“ Vivarium 34, č. 2 (1996): 193-230, S. Meier-Oeser, „,Walter Burley's Propositio in Re and the Systematization of the Ordo Significationis," in Philosophical Debates at Paris in the Early Fourteenth Century, Boston: Brill, 2009, s. 483-505, C. Rode, „Sätze und Dinge: Die propositio in re bei Walter Burley und anderen," Bochumer Philosophisches Jahrbuch für Antike und Mittelalter 10 (2005): 67-90, či J. BIARD, „Le réalisme de Gauthier Burley: logique, métaphysique, épistémologie," Cahiers de philosophie de l'université de Caen 38/39 (2002): 81-105. K propoziční sémantice obecně od antiky po humanismus viz tyto dvě rozsáhlé monografie: G. Nuchelmans, Theories of the Proposition: Ancient and Medieval Conceptions of the Bearers of Truth and Falsity, Amsterdam: North-Holland, 1973, a týž, Late-Scholastic and Humanist Theories of the Proposition, Amsterdam: North-Holland, 1980. Viz také pozn. č. 9 výše.

27 Burley, Commentarius in librum Perihermeneias 1.24, s. 60: „Videndum est cuiusmodi est illud verum vel falsum quod est circa compositionem et divisionem. Circa quod est intelligendum quod Philosophus, VI Metaphysicae, dividit ens in ens reale et ens 
Za druhé je třeba rozlišovat mezi subjektivním bytím (esse subiective) a objektivním bytím (esse obiective). Podle Burleyho má totiž propozice jakožto nositel pravdivostní hodnoty subjektivní bytí v intelektu, a nikoli bytí objektivní. Zde je třeba brát v potaz, že termíny "obiective“ a "subiective" značí v kontextu středověké filosofie něco jiného než v současné filosofii. Je možné říci, že propozice má subjektivní bytí v duši, protože je v duši př́tomna jakožto akcident v substanci. Stejně tak ale můžeme říci, že věc existující mimo mysl má subjektivní bytí. Naopak věc může mít objektivní bytí v duši, pokud je tato věc předmětem (tj. objektem) kognitivního aktu. ${ }^{28}$

Se znalostí těchto dvou distinkcí je možné podívat se na Burleyho definici pravdy:

Proto pravda a nepravda týkající se spojení a rozloučení intelektu je vytvářená intelektem a má v něm subjektivní bytí. Když totiž intelekt správně spojuje či správně rozlučuje, tehdy je pravda v intelektu, a když intelekt nespojuje správně či nerozlučuje správně, konkrétně jako když spojuje ty entity, které jsou v realitě odlišné, nebo rozlučuje ty, které jsou v realitě stejné, tehdy je intelekt nepravdivý. ${ }^{29}$

Burleyho teorie propoziční pravdy je tedy zřejmě korespondenční tvrzení je pravdivé tehdy a jen tehdy, pokud intelekt správně spojuje či správně rozlučuje jisté entity, čímž produkuje entitu novou - pravdivé jsoucno (ens verum), jímž je kladná či záporná propozice. Slučuje či rozlučuje je však správně tehdy a jen tehdy, pokud s tímto spojením či rozloučením nějakým způsobem koresponduje něco v realitě (in re). Jestliže

diminutum - quod est ens in anima; et ens reale dividitur in ens per se et in ens per accidens. Veritas igitur quae est ens diminutum in anima non est similitudo rei in anima, quoniam si anima non plus faceret quam reciperet speciem, cum illa species non distinguatur $a b$ ente reali, sequeretur quod ens non distingueretur in ens reale et in ens diminutum in anima. Et ideo videndum est quid sit illud ens diminutum in anima quod distinguitur contra ens reale. Pro quo est intelligendum quod ens verum quod distinguitur contra ens reale de quo loquitur Philosophus VI Metaphysicae, est aliquid fictum ab anima."

28 K této distinkci obecně viz L. Spruit, Species Intelligibilis: From Perception to Knowledge, 1: Classical Roots and Medieval Discussions, Leiden: Brill, 1994, s. 277-281.

29 Burley, Commentarius in librum Perihermeneias 1.24, s. 61: „Unde veritas et falsitas quae sunt circa compositionem et divisionem intellectus efficitur ab intellectu et habent esse subiective in intellectu. Quando enim intellectus recte componit vel recte dividit, tunc est veritas in intellectu et quando intellectus non componit recte vel non dividit recte, ut scilicet quando componit illa quae in re sunt diversa aut dividit ea ab inviciem quae in re sunt eadem, tunc est intellectus falsus." 
tomu tak není, pak je dané tvrzení nepravdivé. Zde se však nabízí otázka: Co je těmito entitami, které jsou spojovány či rozlučovány intelektem v aktu tvrzení, tj. v aktu vytváření propozice?

Každá propozice vytvořená intelektem se může podle Burleyho skládat bud’ $\mathrm{z}$ psaných termínů $\mathrm{v}$ prípadě propozice psané, $\mathrm{z}$ termínů mluvených u propozice mluvené, nebo z termínů mentálních (tj. pojmů) $\mathrm{v}$ př́padě propozice mentální. Mezi těmito propozicemi existuje jistý rád, ${ }^{30}$ nebot propozice psaná signifikuje propozici mluvenou, a ta zase propozici mentální, která se skládá z pojmů. ${ }^{31}$ Právě kvưli tomuto pořadí mưžeme v prvních dvou př́padech hovořit o sekundárních nositelích pravdivostních hodnot. Bereme-li však v potaz propozici skládající se z mentálních termínů na pozici subjektu a predikátu, je možné hovořit o primárním nositeli pravdivostních hodnot.

Jelikož je však pravda relační vlastností, v tomto př́ípadě vlastností jsoucí v intelektu a náležící jeho výtvoru, tj. mentální propozici složené z pojmů a mající subjektivní bytí v mysli, je nutné nalézt ještě druhé relatum, tj. věc, se kterou je intelekt (či propozice) ve shodě. Tato entita pak má zastávat dvojí roli: je tím, s čím intelekt srovnává mentální propozici, aby zjistil, zda je tato propozice pravdivá (tj. je nástrojem verifikace pojmové propozice, která je primárním nositelem pravdivostní hodnoty), ale také tím, co je touto mentální propozicí přirozeně signifikováno, a co ve své podstatě plní roli konečného signifikátu (tj. toho, co je něčím signifikováno, ale dále již nic nesignifikuje).

$\mathrm{Na}$ otázku, co je tímto konečným signifikátem a tím, na základě čeho lze mentální propozici verifikovat, podává Burley překvapivou odpověd":

K tomu je třeba říci, že v intelektu existuje dvojí propozice: Jedna, která je vytvářena intelektem a má subjektivní bytí v intelektu, a takovou propozici Filosof nazval pravdivým jsoucnem. Jiná je propozice, která má pouze objektivní bytí v intelektu. Tak hovoříme o této větě „Člověk je živočich" podle bytí, jaké v intelektu zaujímá: Intelektem je tak v jednom smyslu produkována tím, že intelekt tvrdí, že člověk a živočich jsou tímtéž; v jiném smyslu má ale „Člověk je živočich" pouze objektiv-

$30 \mathrm{~K}$ tomu viz MeIER-Oeser, „,Walter Burley's Propositio in Re and the Systematization of the Ordo Significationis," s. 483-505.

31 Burley, Commentarius in librum Perihermeneias 1.02, s. 45: „Intelligendum est igitur quod enunciatio habet triplex esse, scilicet in scripto, in prolatione et in mente", a tamtéž 1.13, s. 54: „... passio animae primo significant rem, et vox prolata primo significat passionem animae, et littera scripta primo significat vocem prolatam." 
ní bytí v intelektu. ... Jinými slovy: Můžeme říci, že jedna je propozice in re a jedna v intelektu... ${ }^{32}$

V intelektu tedy existují dvě propozice, které lze označit za mentální. Jedna, která je složená z pojmů, a tu je možné nazvat pravdivým, umenšeným a subjektivním jsoucnem. Tato propozice pak signifikuje jinou mentální propozici, kterou Burley označuje jako „propozici reálnou" (propositio in re) a která má objektivní bytí v mysli, a je tedy pouze předmětem kognitivního aktu. Nicméně zatímco je propozice složená z pojmů produkována intelektem, na němž tak kauzálně závisí, druhá propozice, která je podle Burleyho složená z věcí, na intelektu nezávisí, a nevztahuje se tak na ni ani daná definice pravdy. Jinými slovy, mentální propozice mající objektivní bytí v mysli není ve shodě s věcí, nebot’ jde o samotnou věc. Nikoli však o věc mající subjektivní bytí v realitě, ale věc, jak je uchopena intelektem. O takové propozici pak nemůžeme ř́ci, že je nepravdivá, nebot je pravdivá vždy, podle Burleyho dokonce i tehdy, pokud jí žádný intelekt aktuálně nemyslí. ${ }^{33}$

Po zavedení této distinkce Burley přichází s novou definicí propoziční pravdy $(2 b)$ :

Proto tvrdím, že pravda, která je subjektivně v intelektu, není ničím jiným, než jistou shodou intelektu s pravdivou propozicí, která má pouze objektivní bytí v intelektu. ${ }^{34}$

Podle Burleyho tedy pravdivost propozice složené z pojmů, a v důsledku i propozice psané a mluvené, nejsou verifikovány $\mathrm{v}$ realitě, ale

32 Burley, Commentarius in librum Perihermeneias 1.26, s. 61: „Ad istud dicendum quod in intellectu est duplex propositio: Una quae efficitur ab intellectu et habet esse subiectivum in intelllectu, et talem propositoinem vocat Philosophus ens verum. Alia est propositio quae solum habet esse obiectivum in intellectu. Unde loquendo de ista ,Homo est animal' secundum esse quod habet in intellectu: Sic uno modo efficitur ab intellectu ex hoc quod intellectus asserit hominem et animal esse idem; alio modo ista ,Homo est animal' habet esse obiectivum in intellectu solum. ... Sub aliis verbis: Possumus dicere quod quaedam est propositio in re et quaedam in intellectu..."

33 Burley, Commentarius in librum Perihermeneias 1.27, s. 61: „Unde dico, quod res significata per istam „Homo est animal“ non dependet ab intellectu nec etiam veritas istius rei; immo ista esse vera etsi nullus intellectus consideraret. Et ista similiter ,Chimera est chimera'."

34 Burley, Commentarius in librum Perihermeneias 1.27, s. 61-62: „Unde dico quod veritas quae est subiective in intellectu non est nisi quaedam adaequatio intellectus ad propositionem veram quae solum habet esse obiectivum in intellectu." 
pouze $\mathrm{v}$ realitě jakožto uchopené intelektem. Propozice mající subjektivní bytí v mysli je myslí vytvářena, a lze tak říci, že je kauzálně závislá na vưli individua, jímž je myšlena. $Z$ toho důvodu může být propozice subjektivně existující v mysli nepravdivá. Doctor planus et perspicuus se ale domnívá, že intelekt tyto propozice vytváří z toho, že vnímá jisté vnější komplexní entity, které jsou v tak př́tomny v mysli objektivně. $S$ těmito vnějšími entitami pak daná pojmová mentální propozice koresponduje. ${ }^{35}$

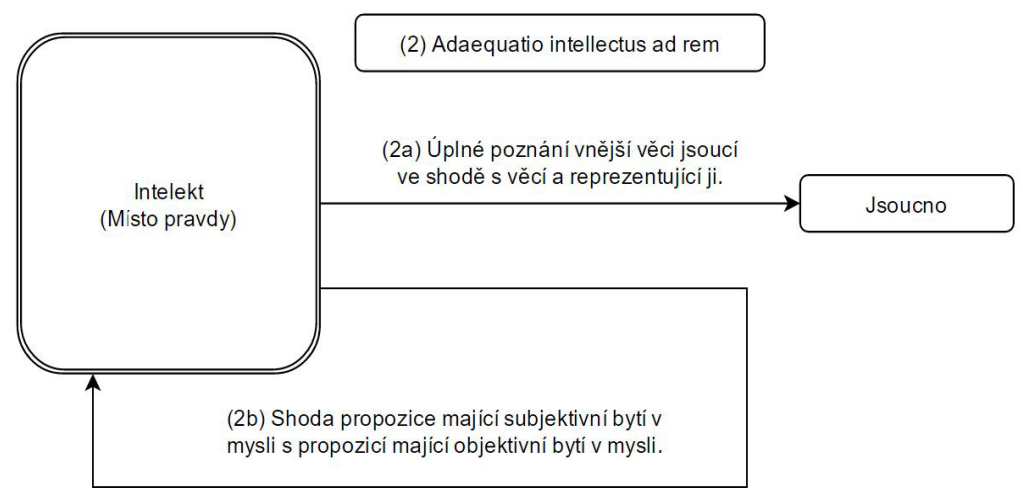

Obr. 2: Pravda jako shoda rozumu s věci

Z toho plyne, jak Burley poznamenává, že propozice, která má subjektivní bytí v mysli, může neexistovat i nebýt pravdivou. Na druhou stranu mentální propozice, která má objektivní bytí v mysli, podle Burleyho nemůže nebýt pravdivou, a dokonce ani nemůže neexistovat, a to ani $\mathrm{v}$ takové situaci, kdy by neexistoval žádný intelekt, který by ji aktuálně zvažoval. Proto kladná propozice "Člověk je živočich“ mající subjektivní bytí může nebýt pravdivou. A pokud ji zrovna žádný intelekt nemyslí, pak taková propozice neexistuje. Nicméně propozice „Člověk je živočich“, která se skládá z věcí uchopených intelektem, nemůže být

35 Burley, Commentarius in librum Perihermeneias 1.27, s. 61: „Istis tamen sic se habentibus in re correspondent propositiones in intellectu quas intellectus efficit ex hoc quod intellectus percipit tales veritates extra." 
nepravdivou. A jelikož je tomu tak, pak musí existovat stále, i pokud ji žádný intelekt nemyslí. ${ }^{36}$

Jak je ovšem možné, že daná reálná propozice mající objektivní bytí $\mathrm{v}$ intelektu existuje nutně a stále, a to i v př́ípadě, že by neexistoval žádný intelekt, který by ji aktuálně myslel, Walter Burley nevysvětluje. Přesto je možné nabídnout alespoň dvě hypotézy:

Za prvé je zřejmé, že Burley počítá s existencí božského intelektu, kterou považuje za nutnou. Ten lze ale chápat tak, že myslí stále a vše, tj. jsou $v$ něm aktuálně přítomné všechny tzv. reálné propozice mající objektivní bytí v jeho intelektu. $V$ takovém př́ípadě by však bylo nutné upravit Burleyho tezi tak, že dané propozice nemohou neexistovat, a to ani v př́padě, že by neexistoval žádný stvořený intelekt, který by je aktuálně myslel. Na druhou stranu, pokud bychom prrijali tuto hypotézu, nebylo by př́liš zřejmé, proč by takovouto nutnou a stálou existenci nemohly mít také propozice mající v božské mysli subjektivní bytí. ${ }^{37}$

Za druhé je možné předpokládat, že dané propozice mající objektivní bytí v intelektu existují v možnosti ve věcech samotných. Jsou-li totiž tzv. reálné propozice věcmi existujícími mimo duši tak, jak jsou uchopeny intelektem, a nemá-li na jejich produkci intelekt žádný vliv, je nutné předpokládat, že ve věcech existuje jistá dispozice $\mathrm{k}$ tvorbě těchto propozic $\mathrm{v}$ intelektu. ${ }^{38} \mathrm{~V}$ takovém př́padě by nebylo problematické tvrdit, že ve věcech existují reálné propozice v možnosti, ačkoli $\mathrm{k}$ jejich uskutečnění je nutná existence intelektu, který by je mohl „vnímat“ či uchopit v kognitivním aktu. Tato hypotéza se pak zdá být pravděpo-

35 Burley, Commentarius in librum Perihermeneias 1.27, s. 62: „Unde dico quod omnes propositiones quae habent esse subiectivum in intellectu humano possunt non esse et etiam possunt non esse verae. Unde ista ,Homo est animal' quae est propositio habens esse subiectivum in intellectu potest non esse, tamen ista ut solum habet esse obiectivum in intellectu non potest non esse nec non esse vera."

Na druhou stranu, tuto hypotézu může podpořit jeden úsek z Burleyho spisu Summa librorum Elenchorum: „Ad illud dicendum quod esse propositionis vel syllogismi non dependet essentialiter a mente mea vel tua, sed essentialiter dependet ab intellectu alicuius intelligentiae a quo numquam recedit." Faktem nicméně zůstává, že s podobným tvrzením se v žádném z jeho dosud editovaných děl nelze setkat. Viz W. BurLEY, "Super tractatum fallaciarum (extractum), “ ed. S. Ebbesen, Cahiers de l'Institut du Moyen-Âge Grec et Latin 74 (2003): 200.

38 Srov. definici (1b), kde se takováto dispozice předpokládá $\mathrm{u}$ věcí v prŕpadě jednoduchého, nekomplexního (tj. nepropozičního) uchopení věcí mimo mysl. Srov. také Aristotelés, O duši 431b 24-26, přel. A. Kříž, Praha: Petr Rezek, 1995, s. 101: „Vědění a vnímání se dělí vzhledem $\mathrm{k}$ předmětům; jedno jest vzhledem k možnému působení předmětů možné, druhé vzhledem k jejich skutečnému působení je skutečné." 
dobnější než předchozí, nebot’ není nutné upravovat Burleyho tvrzení o nemožnosti neexistence těchto propozic, stejně jako není nutné pochybovat o tom, proč propozice mající v mysli subjektivní bytí mohou neexistovat. ${ }^{39}$

ZÁvĚR

Teorii pravdy Waltera Burleyho v podobě, v jaké ji zanechal ve svém středním komentáři k Aristotelovu spisu O vyjadřování, je možné chápat jako verzi korespondenční teorie. Definice, se kterou přichází, je strukturovaná. Na jedné straně je zde relační vlastnost náležející věcem, prostřednictvím které se tyto věci odkrývají intelektu. Je-li intelekt, k nímž je takto věc vztažena, intelektem božským, je pojem pravdy pojmem transcendentálním, nebở se týká všech jsoucen, takže můžeme říci, že je každá věc ve shodě s božským intelektem. $\mathrm{V}$ př́padě intelektu lidského lze pak chápat pravdu jako jistý druh správnosti, nebot jde o to, odkrývá-li se intelektu věc správně (tj. signifikuje-li intelektu pravdu) či nesprávně (signifikuje nepravdu). $V$ prvním prí́padě pak ř́káme, že je daná věc ve shodě $\mathrm{s}$ lidským intelektem, $\mathrm{v}$ druhém prŕpadě, že ve shodě s lidským intelektem není.

Na straně druhé je však pravda relační vlastností, která náleží intelektu. I zde ale existuje pravda dvojího druhu, v závislosti na tom, zda se týká poznání nekomplexního (incomplexa) či komplexního (complexa). V prvním případě se pravda nachází v intelektu tehdy, uchopil-li intelekt jednoduchou quidditu věci a dosáhl-li na její úplné poznání. Tehdy tvrdíme, že je náš intelekt ve shodě s věcí, případně, že je s ní konformní.

39 Rovněž tuto hypotézu lze podpořit textovou evidencí, konkrétně úsekem z kapitoly nazvané De copulatione z Burleyho rozsáhlého logického traktátu De puritate artis logicae, kde autor předkládá své chápání pojmu jsoucna, přičemž jsoucno, které má objektivní bytí v mysli, označuje za jsoucno inteligibilní: „„... dico, quod ens potest accipi tripliciter. Uno modo ut est maxime transcendens et commune omni intelligibili. Et sic est adaequatum obiectum intellectus. Et sic non sequitur: Hoc est ens, ergo hoc est. Secundo modo accipitur pro ente, cui non est esse prohibitum, et sic omne possibile esse est ens. Et sic etiam non sequitur: Hoc est ens, ergo hoc est. Tertio modo accipitur pro ente actualiter existente, et sic est participium descendens ab hoc verbo ,est'. Et isto tertio modo bene sequitur: Hoc est ens, ergo hoc est. Ens primo modo dictum dicitur ens in intellectu, quia est obiectum intellectus; et ita est ens in intellectu obiective. Ens secundo modo dictum dicitur ens in suis causis vel ens quod est in sua causa. Sed ens tertio modo dictum dicitur esse ens in se." Viz W. Burley, De puritate artis logicae, s. 59. 
$\mathrm{V}$ př́ípadě druhém, jak Burley tvrdí ve shodě s Aristotelem, se pravda týká činnosti intelektu, při které jsou jisté entity, které intelekt uchopil, spojovány či rozlučovány, čímž v intelektu vzniká entita mající v něm subjektivní bytí, a kterou označujeme jako „propozici“ či „tvrzení". Tato propozice pak bud' může být ve shodě s věcí, resp. se stavem věcí či faktem, který má v mysli objektivní bytí - tj. se stavem věcí, jak je myslí uchopen, nebo s ním ve shodě není. Tyto „subjektivní“ propozice, jak Burley poznamenává, jsou nahodilé entity produkované činností myslí, které se vyznačují tím, že mohou být nepravdivé a mohou nebýt. Propozice „objektivní" jsou ovšem ve své podstatě nutné, nebot nemohou být nepravdivé ani nemohou neexistovat, přičemž jsou na činnosti (lidského) intelektu zcela nezávislé.

Kromě toho je možné si všimnout zajímavé skutečnosti - struktura Burleyho teorie pravdy totiž v jistém smyslu odráží proces poznání. Definice (1a) je ve své podstatě vyjádřením Boží vševědoucnosti, nebot' nic, co je, nemůže nebýt Bohem nepoznáno. Na rozdíl od této nutnosti, definice (1b) poukazuje na vlastnost, která se skrývá ve věcech vzhledem k lidským kognitivním mohutnostem, nebot každá věc ve své podstatě může být lidským intelektem poznána. Na druhou stranu v tomto smyslu existuje ve věcech také dispozice k oklamání těchto mohutností. $\mathrm{V}$ této definici se pak zrcadlí proces vzniku poznání vedoucí od samotných věcí, skrze médium, smyslový orgán, vnitřní smysly až k intelektu, přičemž, podle Burleyho, je tento proces zcela v režii věci samé. Definice (2a) již počítá s tím, že je tento proces završen, a to tak, že se v lidském intelektu nachází podobnost věci či její reprezentace, kterou tak má již tento intelekt k dispozici. Definice poslední (2b) pak ukazuje, jak vznikají „aristotelská“ pravdivá jsoucna, která může vytvářet každý lidský intelekt prostřednictvím již dříve uchopených reprezentací.

Ve svých pozdních komentářích k Aristotelovým Kategoriím a O vyjadřování si Burley uvědomil některé zásadní nedostatky a nejednoznačnosti, které s jeho ranou teorií souvisí. Ačkoli první tři ze čtyř zmíněných modů pravdy zůstaly $\mathrm{v}$ podstatě $\mathrm{v}$ nezměněné podobě, poslední $\mathrm{z}$ nich, pravda v logickém slova smyslu, doznala nemalých změn. Konkrétně pak v tom, že na ni Burley aplikoval svou supoziční teorii, pravděpodobně $\mathrm{v}$ reakci na některé jiné myslitele, kteří se vydali podobnou cestou. O kladné psané, mluvené i pojmové propozici pak mưžeme dle Burleyho pozdního pojetí ŕíci, že je pravdivá tehdy a jen tehdy, suponuje-li termín na pozici subjektu $v$ konečném signifikátu těchto propozic (tj. $v$ reálné 
propozici) za totéž jako termín $\mathrm{v}$ téže propozici na pozici predikátu, tj. existuje-li mezi těmito dvěma supozity termínů identita. Záporná propozice je pak pravdivá tehdy a jen tehdy, suponuje-li za termín na pozici subjektu reálné propozice za něco jiného než termín na pozici predikátu, $\mathrm{s}$ čímž v realitě koresponduje ne-identita či diversita věcí.

Je zřejmé, že $s$ touto změnou nutně dochází také ke změně funkce a částečně i statusu reálných propozic. Zatímco $\mathrm{v}$ raném pojetí Burley chápal pojmové propozice mající subjektivní bytí v mysli jako primární nositele pravdivostních hodnot a reálné propozice mající objektivní bytí v mysli plnily roli nástroje verifikace těchto propozic (nebot', jak bylo ukázáno výše, tyto propozice nemohou být nepravdivé), v pozdním období zaujaly místo primárních nositelů pravdivostních hodnot právě propozice reálné. Pravda v logickém smyslu z tzv. středního komentáře k Perihermeneias definovaná jako shoda propozice mající subjektivní bytí v mysli s propozicí mající objektivní bytí v mysli, je tak nahrazena definicí, dle které je pravda shoda či korespondence reálné propozice mající objektivní bytí v mysli s uchopeným „,stavem věcí majícím také objektivní bytí v mysli. Zatímco tento uchopený „stav věci“" nemůže být v logickém slova smyslu pravdivý ani nepravdivý, nebot' nejde o propozici (tj. nejde o komplex subjektu, spony a predikátu), vytvoření reálné propozice závisí na vưli intelektu, nebơ právě intelekt je tím, co o věcech něco tvrdí. Od tvrzení, že propozice tohoto druhu nemohou být nepravdivé, se tak Burley ve svém pozdním období odklání, stejně jako od problematické teze, že tyto propozice nemohou neexistovat. Přijímá však přesvědčení jiné, neméně problematické, pro které ovšem rozsáhle argumentuje, konkrétně, že i v případě, že propozice neexistuje, může být stále nositelem pravdivostní hodnoty. ${ }^{40}$

Diskuse, která se v Burleyho pozdních komentárích ke Kategoriím a Perihermeneias zabývá problematikou pravdy, je do značné míry rozsáhlejší než $\mathrm{v}$ raném pojetí. I z toho důvodu je vhodné ponechat ji pro možný budoucí badatelský zájem.

40 Pro danou teorii viz tyto úseky ve zmíněných pozdních komentáŕích: BuRLEY, Expositio super Artem Veterem Porphyrii et Aristotelis, fol g6 ra-g7 rb a k4 ra-rb. 
The Theory of Truth in Walter Burley's Middle Commentary on Aristotle's Perihermeneias

Keywords: Epistemology; Logic; Medieval Philosophy; Ontology; Propositio in re; Semantics; Truth; Walter Burley

Abstract: This study deals with the early theory of truth presented by Walter Burley (ca. 1275-1344) in his so-called middle commentary on Aristotle's Perihermeneias. The issue of truth is raised in the context of Aristotle's claim that truth and falsity imply combination and separation. Burley's dissatisfaction with this purely logical concept of truth leads him to the introduction of a structured definition of truth which allows him to clearly distinguish between truth taken as theological, ontological, epistemological or logical. The first part of this study will present Burley's understanding of truth in the first three of these meanings of truth. The second part will then focus on truth in the logical sense which is also in the center of Burley's own focus of interest. There will also be a discussion of what function his propositional semantics and his theory of so-called real propositions (propositiones in re) have in this theory of truth.

\author{
Mgr. Jakub Varga \\ Katedra filozofie FF OU \\ Reální 5 \\ 70103 Ostrava \\ jakub.varga2@gmail.com
}

